\title{
Phytochemical analysis and acaricidal activity of Aloe arborescens Mill. extracts against Rhipicephalus (Boophilus) microplus
}

\author{
Análise fitoquímica e atividade acaricida de extratos de Aloe \\ arborescens Mill. sobre Rhipicephalus (Boophilus) microplus
}

\author{
Aldair Calistro de Matos $^{1 *}$; Claudia Mello Ribeiro; \\ Ieda Spacinio Scarminio ${ }^{3}$; Sabrina Afonso ${ }^{4}$; Odilon Vidotto ${ }^{5}$
}

\begin{abstract}
The indiscriminate use of chemical acaricides has allowed Rhipicephalus (Boophilus) microplus to develop resistance to several active principles. However, botanical extracts have been tested as an alternative method to control those ticks. This experiment studied the chemical fingerprint and acaricidal effect of fresh and dry Aloe arborescens Mill. extracts on $R$. (B.) microplus. The acaricidal activity of extracts was assessed using in vitro assays with engorged females, and phytochemical characterization was performed by infrared (IR) spectroscopy and high-performance liquid chromatography (HPLC). The results showed that fresh and dry A. arborescens extracts prepared with the solvents pure ethanol, ethanol-dichloromethane binary mixture, and ethanol-dichloromethane-acetone ternary mixture, contained water-soluble tannins and had a strong effect on the reproductive parameters of $R$. $(B$. microplus demonstrated by a marked decreased in the number of eggs laid and in the larvae hatching rate $(\mathrm{p}<0.05, \mathrm{p}<0.01, \mathrm{p}<0.001)$. In conclusion, $A$. arborescens Mill. has components with acaricidal activity against $R$. (B.) microplus, and phytotherapy with extracts of this plant may be used as an alternative method of $R$. (B.) microplus control.
\end{abstract}

Key words: Acaricide. Botanical extracts. Bovines. Control. Phytotherapy. Ticks.

\section{Resumo}

O uso indiscriminado de acaricidas químicos permitiu o desenvolvimento de resistência de Rhipicephalus (Boophilus) microplus a vários princípios ativos. Entretanto, extratos botânicos têm sido testados como método alternativo para o controle desses carrapatos. Este experimento foi conduzido para estudar a impressão digital química e o efeito acaricida de extratos frescos e desidratados de Aloe arborescens Mill sobre R. (B.) microplus. A atividade acaricida dos extratos foi avaliada por meio de testes in vitro com fêmeas ingurgitadas e a caracterização fitoquímica foi determinada por espectroscopia no infravermelho (IV) e cromatografia líquida de alta eficiência (HPLC). Os resultados demostraram que os extratos frescos e desidratados de $A$. arborescens Mill obtidos com os solventes etanol puro, mistura binária de etanol e diclorometano, e mistura ternária de etanol, diclorometano e acetona, continham taninos hidrossolúveis e apresentaram maior atividade acaricida sobre os parâmetros reprodutivos de

${ }^{1}$ M.e, em Química, Departamento de Medicina Veterinária Preventiva, Universidade Estadual de Londrina, UEL, Londrina, PR, Brasil. E-mail: aldair@uel.br

2 Prof. Dr., Universidade Comunitária da Região de Chapecó, UNOCHAPECÓ, Chapecó, SC, Brasil. E-mail: claudiaribeiro@, unochapeco.edu.br

3 Prof. Dr., Departamento de Química, UEL, Londrina, PR, Brasil. E-mail: ieda@uel.br

${ }^{4}$ Prof. Dr., Universidade Estadual Paulista Júlio de Mesquita Filho, UNESP, Bauru, SP, Brasil. E-mail: sabrina_quimica@hotmail. com

5 Prof. Dr., Departamento de Medicina Veterinária Preventiva, UEL, Londrina, PR, Brasil. E-mail: vidotto@uel.br

* Author for correspondence 
$R$. (B.) microplus, pois observou-se queda acentuada no número de ovos postos e na taxa de eclosão das larvas $(\mathrm{p}<0,05 ; \mathrm{p}<0,01 ; \mathrm{p}<0,001)$. Conclui-se que $A$. arborescens Mill possui componentes com efeito acaricida contra $R$. (B.) microplus e que a fitoterapia, com os extratos dessa planta, pode ser utilizada como método alternativo para o controle de $R$. (B.) microplus.

Palavras-chave: Acaricida. Bovinos. Carrapatos. Controle. Extratos botânicos. Fitoretapia.

\section{Introduction}

The tick R. (B.) microplus is one of the most important bovine parasites, especially in tropical and subtropical regions, because it causes annual losses estimated in tens of billions of dollars through the decrease in herd productivity, devaluation of leather, and high expenditure on supplies for cattle treatment. Furthermore, it is responsible for transmitting Babesia bovis, Babesia bigemina, and Anaplasma marginale, etiologic agents of bovine babesiosis and anaplasmosis (JONSSON, 2006; GRISI et al., 2014).

Currently, R. (B.) microplus control strategies involve the use of synthetic acaricides. However, alternative methods must be developed for more effective control of this ectoparasite, given the increase in acquired resistance to these products, high treatment costs, and environmental contamination (ROBBERTSE et al., 2016; WYK et al., 2016).

Phytotherapy is considered a key alternative for tick control because it may reduce the economic and environmental impacts of using chemical acaricides. Biologically active botanicals have shown acaricidal activity causing oviposition inhibition, infertility, and mortality of Ixodidae ticks, including $R$. (B.) microplus (GIGLIOTI et al., 2011; CAMPOS et al., 2015), Rhipicephalus sanguineus (POLITI et al., 2012), Amblyomma cajennense (CAMPOS et al., 2015), Amblyomma americanum and Dermacentor variabilis (CARROLL et al., 1989), and Hyalomma excavatum (ABDEL-SHAFY; ZAYED, 2002).

Aloe L. is a botanical genus belonging to the Xanthorrhoeaceae family that consists of 550 plant species of African origin, which are known for their medicinal and cosmetic properties; however, only the Aloe vera, A. perryi Baker, A. ferox Mill., and $A$. arborecens Mill. species are important for international trade (BJORÅ et al., 2015). Thus far, no data on the activity of $A$. arborescens against ticks have been reported. The present study aimed to characterize the chemical profile of fresh and dry $A$. arborescens leaf extracts and assess their in vitro effects on the reproductive parameters of $R$. (B.) microplus engorged females.

\section{Material and Methods}

Aloe arborescens Mill

A. arborescens leaves were collected from the planting bed of the Department of Chemistry, Londrina State University (Universidade Estadual de Londrina), Paraná (23 18' 36" S, 51 ${ }^{\circ} 9^{\prime} 46^{\prime \prime}$ W). Control samples were herborized and deposited in the Londrina State University Herbarium (Herbário da Universidade Estadual de Londrina - FUEL) to identify and deposit the voucher specimen (FUEL No. 46852).

\section{Extract preparation}

Approximately $75 \mathrm{~g}$ of fresh or dry A. arborescens leaves were homogenized in $120 \mathrm{~mL}$ of the respective solvents, according to an experimental design of simplex-centroid mixtures (Figure 1). The triangle vertices are the pure solvents ethanol (Vetec Quimíca Fina $^{\circledR} ; 1$ ), dichloromethane (Vetec Quimíca Fina $^{\circledR} ; 2$ ), and acetone (Vetec Quimíca Fina ${ }^{\circledR} ; 3$ ); the edges $(4,5$, and 6$)$ are the solvent binary mixtures at $1: 1$ ratio $(\mathrm{v} / \mathrm{v})$; the central point $(7)$ is a ternary mixture of three solvents at 1:1:1 ratio $(\mathrm{v} / \mathrm{v} / \mathrm{v})$; and the axial points 8,9 and 10 are the ternary mixtures at $2: 1: 1 \mathrm{ratio}(\mathrm{v} / \mathrm{v} / \mathrm{v})$. The aqueous extracts $(11)$ were prepared using $75 \mathrm{~g}$ fresh leaves or $10 \mathrm{~g}$ dry leaves subjected to extraction with $600 \mathrm{~mL}$ distilled water 
at $60{ }^{\circ} \mathrm{C}$ for $30 \mathrm{~min}$. The extracts were subjected to an ultrasound bath for $30 \mathrm{~min}$, filtered and brought to evaporation. Subsequently, the concentrated extracts were kept at room temperature. The ratios used to prepare the various mixtures are outlined in Table 1.

Figure 1. Experimental design of the simplex-centroid mixture formulation for Aloe arborescens Mill. extracts used on the treatment of Rhipicephalus (Boophilus) microplus.

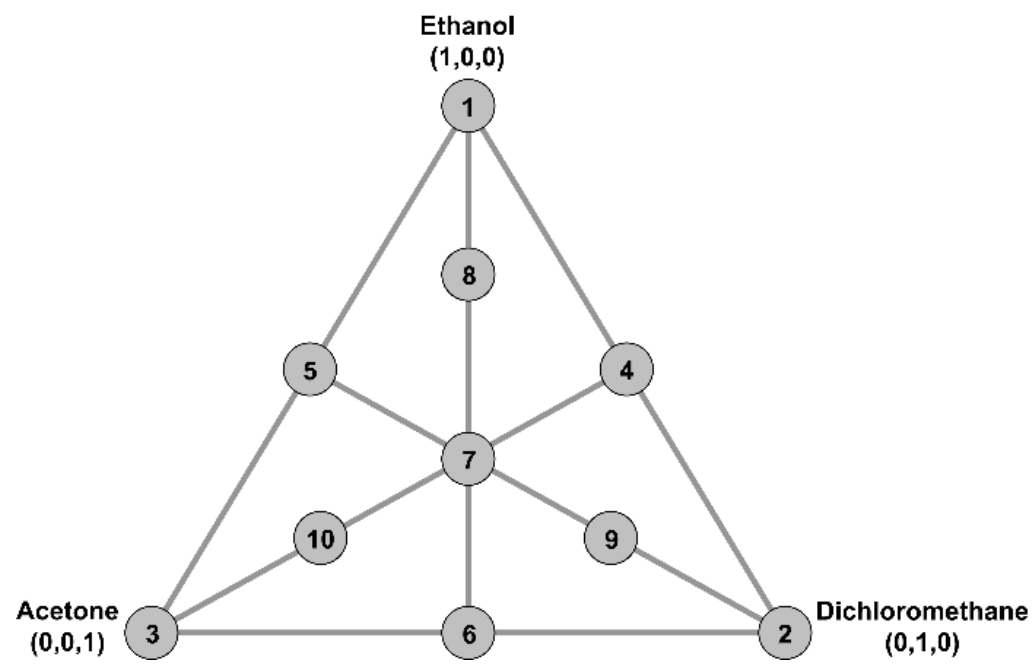

Table 1. Ratios of the solvents ethanol, dichloromethane, acetone, and water, used to prepare Aloe arborescens Mill. extracts.

\begin{tabular}{ccccc}
\hline Extract & $\begin{array}{c}\text { Ethanol } \\
(\%)\end{array}$ & $\begin{array}{c}\text { Dichloromethane } \\
(\mathbf{\%})\end{array}$ & $\begin{array}{c}\text { Acetone } \\
(\%)\end{array}$ & $\begin{array}{c}\text { Water } \\
\mathbf{( \% )}\end{array}$ \\
\hline $\mathbf{1}$ & 100.0 & - & - & - \\
$\mathbf{2}$ & - & 100.0 & - & - \\
$\mathbf{3}$ & - & - & 100.0 & - \\
$\mathbf{4}$ & 50.0 & 50.0 & - & - \\
$\mathbf{5}$ & 50.0 & - & 50.0 & - \\
$\mathbf{6}$ & - & 50.0 & 50.0 & - \\
$\mathbf{7}$ & 33.3 & 33.3 & 33.3 & - \\
$\mathbf{8}$ & 50.0 & 25.0 & 25.0 & - \\
$\mathbf{9}$ & 25.0 & 50.0 & 25.0 & - \\
$\mathbf{1 0}$ & 25.0 & 25.0 & 50.0 & - \\
$\mathbf{1 1}$ & - & - & - & 100.0 \\
\hline
\end{tabular}

\section{Phytochemical analysis of extracts}

Chemical fingerprinting of the $11 \mathrm{~A}$. arborescens extracts prepared was performed by Fouriertransform infrared (FTIR) spectroscopy and high-performance liquid chromatography (HPLC) as described by Afonso et al. (2015). For chromatographic analysis,
$0.005 \mathrm{~g}$ of each crude extract was diluted in $10 \mathrm{~mL}$ extraction solvent and subjected to an ultrasound bath for $15 \mathrm{~min}$. The supernatant was filtered through a fluoropore membrane (Millex, Millipore ${ }^{\circledR}$ ). The chromatograms of the extracts were obtained using Finnigan $^{\mathrm{TM}}$ Sourveyor ${ }^{\mathrm{TM}}$ and the high-performance 
liquid chromatograph (Thermo Scientific ${ }^{\circledR}$ ) with SPD-M10AV photodiode array detector (PDA), Metasil ODS C18 column PN0380 Metachen 250 $\mathrm{mm} \times 4.6 \mathrm{~mm}, 5 \mu \mathrm{m}$ particle size. Monitoring was performed at $210 \mathrm{~nm}$ wavelength and the composition of the mobile phase used was $68 \%$ $\mathrm{H}_{2} \mathrm{O}$ and $32 \% \mathrm{CH}_{3} \mathrm{CN}$, injecting $20 \mu \mathrm{L}$ of sample into the manual injection system. The original data from those chromatograms were converted into a matrix with 4801 rows $\times 11$ columns, wherein rows corresponded to the retention time in a 40 min run, which provided no relevant data after $20 \mathrm{~min}$ of elution, and columns corresponded to the extracts from the solvent mixture with the aqueous extract.

The spectra of crude extracts were obtained by infrared spectroscopy using the FTIR- 800 spectrophotometer $\left(\right.$ Shimadzu $\left.^{\circledR}\right)$ and recorded in the spectral region between $4000-400 \mathrm{~cm}^{-1}$ using a detachable sample holder for samples with potassium bromide tablets $\left(\right.$ Synth $\left.^{\circledR}\right)$.

\section{Rhipicephalus (Boophilus) microplus bioassay}

$R$. (B.) microplus engorged females larger than $4.5 \mathrm{~mm}$ were collected from naturally infested Holstein cattle from a farm in the municipality of Londrina after a 50-day period without acaricides. Ticks were sent to the laboratory and identified in accordance with criteria set out by Aragão and Fonseca (1961).

The immersion test was used for the $R$. (B.) microplus bioassays as reported by Drummond et al. (1973). The extracts were used at a $700 \mathrm{mg}$ $\mathrm{mL}^{-1}$ concentration. For the treatments, ticks with similar masses were separated into groups of 10 and immersed in $10 \mathrm{~mL}$ of extract solution for $5 \mathrm{~min}$. The control group consisted of engorged females immersed in distilled water. The ticks were incubated in a biochemical oxygen demand (BOD) incubator at $27 \pm 1{ }^{\circ} \mathrm{C}$ and $70 \pm 5 \%$ relative humidity for 15 days. At the end of that period, the eggs laid in the groups were collected, weighed and incubated in a BOD incubator under the same conditions for a further 15 days. Após, os ovos e as larvas eclodidas foram contados com o auxílio de uma lupa. Twelve hundred units (eggs and larvae) were counted in each extract tested.

The data collected in the assays with $R$. (B.) microplus were used to determine the following parameters: oviposition index (OI), oviposition inhibition (OIN) rate, and hatching $(\mathrm{H})$ rate, according to the formulae reported by Stendel (1980); and reproductive efficiency (RE) and product efficiency (PE) according to the equations proposed by Drummond et al. (1973):

$\mathrm{OI}=$ egg mass $/$ female mass

$\% \mathrm{OIN}=\left[\left(\mathrm{OIN}_{\text {(control) }}-\mathrm{OIN}_{(\text {treated }}\right) / \mathrm{OIN}_{(\text {control) }}\right] \times 100$ $\% \mathrm{H}=$ (number of larvae observed / number of larvae estimated) $\times 100$

$\mathrm{RE}=($ egg mass $\times \%$ hatching $\times 20.000) /$ female mass

$\% \mathrm{PE}=\left[\left(\mathrm{RE}_{\text {(control) }}-\mathrm{RE}_{\text {(treated) }} / \mathrm{RE}_{\text {(control) }}\right] \times 100\right.$

\section{Statistical analysis}

The experimental design for assessment of $R$. (B.) microplus reproductive parameters was completely randomized, with eleven treatments and two replicates. Reproductive parameters were subjected to analysis by the Student's t-test using the Statistical Analysis System software version $9.3\left(\mathrm{SAS}^{\circledR}\right)$. The analysis tested whether these parameters differed between fresh and dry A. arborescens extracts and types of extraction solvents used. The differences among the means of reproductive parameters were compared using the Tukey test. All comparisons were performed at the $5 \%$ significance level.

\section{Results}

In this experiment, chemical fingerprinting and the acaricidal effect of $11 \mathrm{~A}$. arborescens extracts prepared with the solvents ethanol, acetone, dichloromethane, and water, on the reproductive parameters of $R$. (B.) microplus engorged female ticks was assessed. 
The effects of the 11 extracts on the $R$. (B.) microplus OI, OIN (\%), and $\mathrm{H}(\%)$ are outlined in Table 2. The results showed significant differences in the effects of fresh extracts one, two, four, and eight compared with the control group, considering the OI $(\mathrm{p}<0.05 ; \mathrm{p}<0.01)$ and the $\mathrm{H}$ rate $(\mathrm{p}<0.05 ; \mathrm{p}<0.01$; $\mathrm{p}<0.001)$. However, only dry extracts four and eight significantly reduced these parameters $(p<0.05)$.

Table 2. Means ( \pm SEM) of the oviposition index (OI), oviposition inhibition rate $(\%$ OIN) and egg hatching rate $(\%$ EH) of Rhipicephalus (Boophilus) microplus treated with fresh and dry Aloe arborescens Mill. leaf extracts.

\begin{tabular}{|c|c|c|c|c|c|c|}
\hline \multirow{2}{*}{ Extract } & \multicolumn{3}{|c|}{ Fresh leaves } & \multicolumn{3}{|c|}{ Dry leaves } \\
\hline & OI (g) & $\%$ OIN & $\% \mathrm{H}$ & OI (g) & $\%$ OIN & $\% \mathrm{H}$ \\
\hline 1 & $0.09 \pm 0.03 * *$ & $66.10 \pm 3.40^{\mathrm{a}}$ & $47.08 \pm 1.48^{* *}$ & $0.19 \pm 0.08$ & $48.20 \pm 3.80$ & $60.91 \pm 2.75$ \\
\hline 2 & $0.11 \pm 0.03^{*}$ & $59.85 \pm 1.44$ & $61.78 \pm 1.78^{*}$ & $0.20 \pm 0.11$ & $40.50 \pm 5.00$ & $70.82 \pm 7.41$ \\
\hline 3 & $0.18 \pm 0.06$ & $37.20 \pm 5.90$ & $49.30 \pm 1.70 *$ & $0.29 \pm 0.07$ & $36.15 \pm 4.65$ & $68.74 \pm 1.84$ \\
\hline 4 & $0.06 \pm 0.01^{* *}$ & $74.89 \pm 2.79^{\mathrm{a}}$ & $26.24 \pm 0.35^{\mathrm{a} * * *}$ & $0.11 \pm 0.09 *$ & $66.85 \pm 8.45^{a}$ & $40.79 \pm 0.20^{\mathrm{a} *}$ \\
\hline 5 & $0.17 \pm 0.02$ & $55.80 \pm 5.50$ & $50.05 \pm 4.94^{*}$ & $0.22 \pm 0.09$ & $36.20 \pm 10.90$ & $69.04 \pm 0.29$ \\
\hline 6 & $0.19 \pm 0.07$ & $53.65 \pm 8.55$ & $48.79 \pm 1.99 *$ & $0.18 \pm 0.08$ & $46.25 \pm 1.04$ & $63.83 \pm 4.50$ \\
\hline 7 & $0.19 \pm 0.07$ & $34.15 \pm 18.25$ & $57.22 \pm 2.78^{*}$ & $0.20 \pm 0.09$ & $40.65 \pm 3.35$ & $71.23 \pm 1.67$ \\
\hline 8 & $0.07 \pm 0.01 * *$ & $73.20 \pm 2.60^{\mathrm{a}}$ & $34.41 \pm 6.78^{a * *}$ & $0.12 \pm 0.07^{*}$ & $63.75 \pm 7.84^{\mathrm{a}}$ & $43.87 \pm 1.87^{\mathrm{a} *}$ \\
\hline 9 & $0.23 \pm 0.01$ & $20.45 \pm 12.85$ & $63.63 \pm 5.03$ & $0.20 \pm 0.09$ & $40.45 \pm 2.25$ & $75.15 \pm 2.59$ \\
\hline 10 & $0.24 \pm 0.07$ & $16.20 \pm 5.50$ & $67.84 \pm 2.17$ & $0.20 \pm 0.07$ & $42.75 \pm 3.95$ & $69.87 \pm 2.45$ \\
\hline 11 & $0.23 \pm 0.12$ & $34.60 \pm 0.05$ & $74.46 \pm 0.53$ & $0.25 \pm 0.02$ & $28.45 \pm 2.25$ & $71.33 \pm 3.66$ \\
\hline Control & $0.35 \pm 0.01$ & - & $73.17 \pm 10.37$ & $0.29 \pm 0.03$ & - & $80.06 \pm 3.48$ \\
\hline
\end{tabular}

Values followed by the same letter in columns are not significantly different, according to the Tukey's test $(p<0.05)$ Values significantly different from the control group at $p<0.05(*), p<0.01(* *)$ and $p<0.001(* * *)$.

The reproductive efficiency of $R$. (B.) microplus engorged females decreased significantly after exposure to treatments with fresh extracts one, four and eight, and dry extracts four and eight $(\mathrm{p}<0.05)$, showing high efficacy rates of these extracts, which ranged from $79-86 \%$ in fresh extracts and $82-83 \%$ in dry extracts (Table 3 ).

The spectral data of fresh and dry extracts of $A$. arborescens are shown in Figure 2.

Table 3. Means ( \pm SEM) of reproductive efficiency (RE) and product efficiency (PE) rate assessed in the assays with Rhipicephalus (Boophilus) microplus treated with fresh or dry Aloe arborescens Mill. extracts.

\begin{tabular}{|c|c|c|c|c|}
\hline \multirow{2}{*}{ Extract } & \multicolumn{2}{|l|}{ Fresh leaves } & \multicolumn{2}{|c|}{ Dry leaves } \\
\hline & $\mathbf{R E}$ & $\% \mathrm{PE}$ & $\mathbf{R E}$ & $\% \mathrm{PE}$ \\
\hline 1 & $129493.3 \pm 48840.2^{a *}$ & $79.89 \pm 5.29^{\mathrm{a}}$ & $476900.3 \pm 13010.1$ & $70.13 \pm 0.56$ \\
\hline 2 & $288832.7 \pm 53488.4$ & $66.90 \pm 1.40$ & $490080.1 \pm 3675.7$ & $47.12 \pm 0.77$ \\
\hline 3 & $285613.8 \pm 128316.7$ & $51.95 \pm 5.75$ & $513500.0 \pm 3686.4$ & $44.61 \pm 7.99$ \\
\hline 4 & $81253.3 \pm 38098.0^{\mathrm{a} *}$ & $86.45 \pm 1.25^{\mathrm{a}}$ & $151594.1 \pm 31865.3^{a *}$ & $83.61 \pm 3.70^{\mathrm{a}}$ \\
\hline 5 & $323518.1 \pm 110282.8$ & $44.80 \pm 5.00$ & $508259.1 \pm 72038.1$ & $45.16 \pm 7.16$ \\
\hline 6 & $331862.8 \pm 191555.1$ & $43.35 \pm 4.85$ & $398010.1 \pm 164648.5$ & $57.06 \pm 1.96$ \\
\hline 7 & $344115.3 \pm 51041.1$ & $41.30 \pm 14.50$ & $494350.2 \pm 160652.3$ & $46.66 \pm 6.63$ \\
\hline 8 & $79250.2 \pm 8717.6^{\mathrm{a} *}$ & $85.55 \pm 0.45^{\mathrm{a}}$ & $165992.2 \pm 4587.0^{a *}$ & $82.08 \pm 3.61^{\mathrm{a}}$ \\
\hline 9 & $379021.2 \pm 64317.5$ & $35.40 \pm 11.40$ & $519745.1 \pm 258299.0$ & $43.98 \pm 2.31$ \\
\hline 10 & $421860.1 \pm 102342.0$ & $28.00 \pm 7.20$ & $464768.2 \pm 192758.7$ & $49.81 \pm 3.99$ \\
\hline 11 & $497215.8 \pm 288112.5$ & $15.10 \pm 2.50$ & $592000.3 \pm 492000.2$ & $36.13 \pm 1.56$ \\
\hline Control & $440453.5 \pm 75337.2$ & - & $926796.4 \pm 37061.8$ & - \\
\hline
\end{tabular}

Values followed by the same letter in columns are not significantly different, according to the Tukey's test $(p<0.05)$

Values significantly different from the control group at $p<0.05(*)$. 
Figure 2. Infrared spectra of $11 \mathrm{~A}$. arborescens Mill. extracts used on the treatment of Rhipicephalus (Boophilus) microplus. (A) Fresh leaf extracts with bands characteristic of aloeresin E (2), aloenin B (1), aloin A (5, 7, and 10), aloin B (1), 4'-O-glucosyl-isoaloeresin (2, 3, 4, 5, 6, 7, 9, and 10), and water-soluble (1, 2, 3, 4, 5, 6, 7, 8, 9, 10, and 11) and condensed (1) tannins. (B) Dry leaf extracts with aloeresin E (1 and 3), aloeresin A (1), aloin A (1, 3, 4, 8, 9, and 10), aloenin B $(2,4,6,7,8$, and 10), 4'-O-glucosyl-isoaloeresin $(3,4,7,8,9$, and 10), homonataloin (8 and 10) and water-soluble $(4,6$, and 8$)$ and condensed $(1,5$ and 6$)$ tannin bands

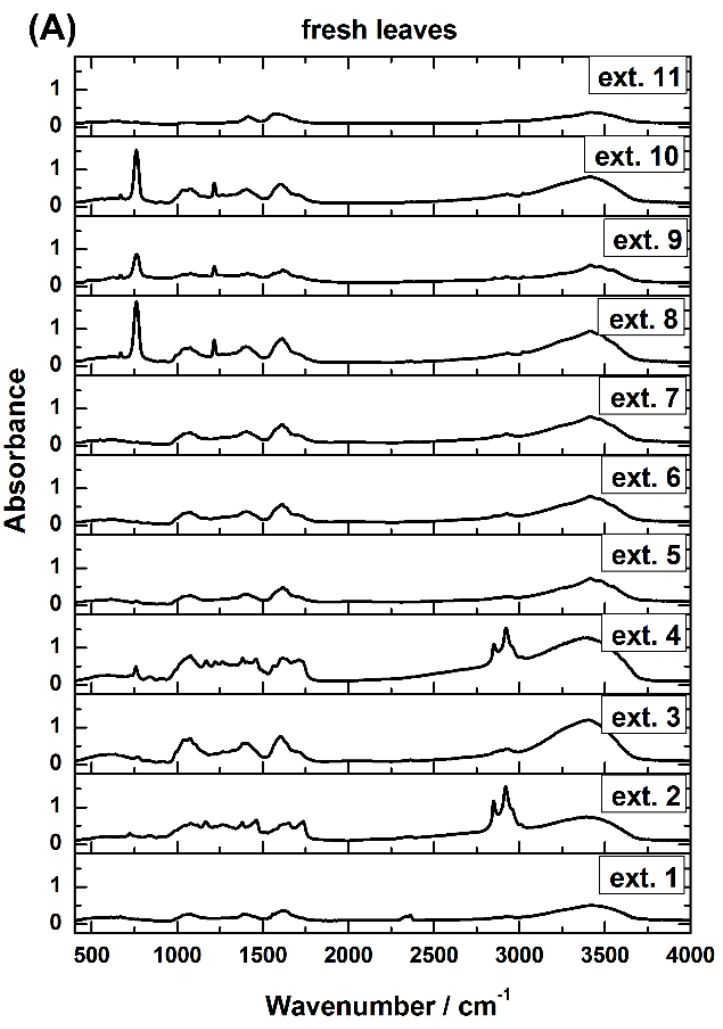

The bands present around 900-675 $\mathrm{cm}^{-1}$ characterize angular deformation vibrations outside the C-H plane of polynuclear aromatic hydrocarbons and in-phase deformations outside the plane of adjacent hydrogen atoms of the aromatic rings, which were strongly coupled to each other.

The bands around 1230-1000 $\mathrm{cm}^{-1}$ were compatible with asymmetric axial deformation of ether $\mathrm{C}-\mathrm{O}$ bonds and characteristic of alcohol and phenol C-O stretching.

The bands present in the spectral region 2900$2700 \mathrm{~cm}^{-1}$ were compatible with Csp3-H stretching in alkanes. The bands $1690-1470 \mathrm{~cm}^{-1}$ indicate $\mathrm{C}-\mathrm{N}$ group stretching in alkylamines. The spectral

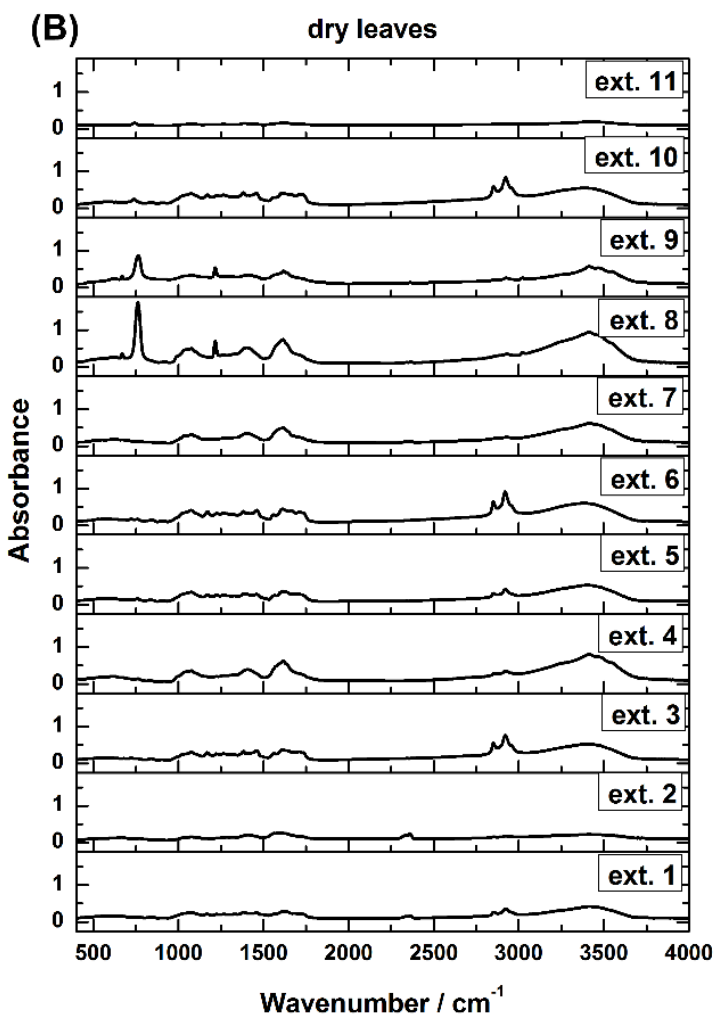

region 3400-3550 $\mathrm{cm}^{-1}$ showed an $\mathrm{N}-\mathrm{H}$ angular deformation vibration present in alkaloids.

The band $3400 \mathrm{~cm}^{-1}$ indicated stretching vibration of $\mathrm{O}-\mathrm{H}$ bonds present in alcohols and phenols.

The bands between 1650 and $1800 \mathrm{~cm}^{-1}$ characterize $\mathrm{C}=\mathrm{O}$ double bond stretching of the carbonyl group.

The phytochemical characterization of the extracts enabled identification of the presence of condensed and water-soluble tannins, in addition to anthraquinones, including aloeresin, aloenin, aloin $\mathrm{A}$ and $\mathrm{B}$, homonataloin, and 4'-O-glucosylisoaloeresin. Water-soluble tannins were the main components of the extracts with the highest 
acaricidal activity, namely fresh extracts one, two, four, and eight, and dry extracts four and eight (Figure 2).

\section{Discussion}

Various bioactive components of plant extracts have shown acaricidal activity against $R$. (B.) microplus. Chrysopogon zizanioides extracts containing zizanoic and khusimol acids significantly reduce the egg production and oviposition index of A. cajennense and $R$. (B.) microplus at 20, 50, and $100 \mu \mathrm{L} \mathrm{mL}^{-1}$ concentrations (CAMPOS et al., 2015). Carvacrol and thymol extracted from Lippia gracilis at 4.46 and $5.50 \mathrm{mg} \mathrm{mL}^{-1}$ concentrations resulted in $50 \%$ lethality $\left(\mathrm{CL}_{50}\right)$ for $R$. (B.) microplus females, respectively (CRUZ et al., 2013). The efficacy of Azadirachta indica extracts containing 10,000 ppm azadirachtin against $R$. (B.) microplus was $94 \%$, albeit without causing larval mortality (GIGLIOTI et al., 2011). Scopolamine, the active component of Atropa belladonna, caused $93 \%$ mortality of the $R$. (B.) microplus females tested at $0.1 \%$ concentration (GODARA et al., 2014).

Aloe is a genus characterized by the presence of anthraquinones, polyphenols, saponins, vitamins and minerals (LUCINI et al., 2015; RAHMANI et al., 2015). In this study, the qualitative analysis of the chemical composition of $A$. arborescens extracts showed that only water-soluble tannins were present in all fresh extracts, which indicates that all solvents (pure or mixed) were effective in the extraction of these secondary metabolites (Figure 2). Water-soluble tannins were only observed in the dry extracts four, six, and eight, which suggests that the extraction of these components requires a synergistic effect between the water present in the leaves and the solvents used in the other extracts. Extracts with water-soluble tannins prepared using the solvents pure ethanol, ethanol-dichloromethane binary mixture, and ethanol-dichloromethaneacetone ternary mixture, were the most effective against $R$. (B.) microplus (Tables 1 and 2).
Tannins are the most abundant secondary metabolites in tropical plants (BARBEHENN; PETER CONSTABEL, 2011) and have shown antiparasitic activity. The anthelmintic activity of water-soluble tannins determined a reduction in the percentage of hatchability and motility of first and second stages larvae of Haemonchus contortus (ENGSTRÖM et al., 2016). Water-soluble tannins also have activity against protozoa, causing the death of Giardia duodenalis trophozoites (ANTHONY et al., 2011).

Previous studies reported the acaricidal activity of tannin-rich plants against mites and ticks. Afify et al. (2011) examined the effects of Syzygium cumini extracts containing tannins and produced with different solvents on the Tetranychus urticae mite viability. The results showed that the extract produced using a concentration of $300 \mu \mathrm{g} \mathrm{mL}-1$ ethanol had the best acaricidal activity, causing 100 $\%$ mite mortality. Lippia origanoides and Gliricidia sepium ethanolic extracts at $5 \%$ concentration decreased the oviposition index of the Tetranychus cinnabarinus mite to $43.7 \%$ and $57.0 \%$, respectively. At $10 \%$ concentration, L. origanoides and G. sepium extracts caused $42.2 \%$ and $72.5 \%$ T. cinnabarinus mortality, respectively (SIVIRA et al., 2011).

In this experiment the oviposition index and the hatching percentage were significantly reduced after treatment of engorged females with tannin fresh extracts 1, 2, 4 and 8, and dehydrated 4 and 8. These results difer from the Fernández-Salas et al. (2011) who observed that the extracts of Acacia pennatula, Piscidia piscipula, Leucaena leucocephala and Lysiloma latisiliquum, rich in tannins, had no significant effects on the oviposition index of $R$. (B.) microplus females. Additional studies should be conducted to evaluate the effects of tannins on the reproductive parameters of engorged females of R. (B.) microplus. 


\section{Conclusion}

In conclusion, fresh and dry $A$. arborescens extracts prepared with the solvents pure ethanol, ethanol-dichloromethane binary mixture, and ethanol-dichloromethane-acetone ternary mixture, contain water-soluble tannins and demonstrated in vitro acaricidal activity against $R$. (B.) microplus engorged females. This shows that the use of such extracts may be a key phytotherapeutic alternative for controlling infestations of $R$. (B.) microplus, However, in vivo studies are necessary to establish the acaricidal potential of these extracts in cattle.

\section{References}

ABDEL-SHAFY, S.; ZAYED, A. A. In vitro acaricidal effect of plant extract of nem seed oil (Azadirachta indica) on egg, immature, and adult stages of Hyalomma anatolicum excavatum (Ixodoidea: Ixodidae). Veterinary Parasitology, Amsterdam, v. 106, n. 1, p. 89-96, 2002.

AFIFY, A. EL-M.; EL-BELTAGI, H. S.; FAYED, S. A.; SHALABY, E. A. Acaricidal activity of different extracts from Syzygium cumini L. Skeels (Pomposia) against Tetranychus urticae Koch. Asian Pacific Journal of Tropical Biomedicine, Haikou, v. 1, n. 5, p. 359-364, 2011.

AFONSO, S.; MATOS, A. C.; MARENGO, V. A.; MOREIRA, E. G.; SOARES, D. X.; KOOLEN, H. H. F.; SCARMINIO, I. Seasonal effects on HPLC-DAD-UV and UPLC-ESI-MS fingerprints and analgesic activities of Vernonia condensata Baker extracts. Journal of the Brazilian Chemical Society, Campinas, v. 26, n. 2, p. 350-358, 2015.

ANTHONY, J. P.; FYFE, L.; STEWART, D.; MCDOUGALL, G. J. Differential effectiveness of berry polyphenols as anti-giardial agents. Parasitology, London, v. 138, n. 9, p. 1110-1116, 2001.

ARAGÃO, H. B.; FONSECA, F. Notas de ixodologia. VII Lista e chave para os representantes da fauna ixodológica brasileira. Memórias do Instituto Oswaldo Cruz, Rio de Janeiro, v. 59, n. 2, p. 115-129, 1961.

BARBEHENN, R. V.; PETER CONSTABEL, C. Tannins in plant-herbivore interactions. Phytochemistry, London, v. 72, n. 13, p. 1551-1565, 2011.

BJORÅ, C. S.; WABUYELE, E.; GRACE, O. M.; NORDAL, I.; NEWTON, L. E. The uses of Kenyan aloes: an analysis of implications for names, distribution and conservation. Journal of Ethnobiology and Ethnomedicine, London, v. 25, n. 11, p. 82, 2015.

CAMPOS, R. N.; NASCIMENTO LIMA, C. B.; PASSOS OLIVEIRA, A.; ALBANO ARAÚJO, A. P.; FITZGERALD BLANK, A.; BARRETO ALVES, P.; NASCIMENTO LIMA, R.; ALBANO ARAÚJO, V;; SANTANA, A. S.; BACCI, L. Acaricidal properties of vetiver essential oil from Chrysopogon zizanioides (Poaceae) against the tick species Amblyomma cajennense and Rhipicephalus (Boophilus) microplus (Acari: Ixodidae). Veterinary Parasitology, Amsterdam, v. 212, n. 3-4, p. 324-330, 2015.

CARROLL, J. F.; MARADUFU, A.; WARTHEN, J. D. J. An extract of Commiphora erythraea: a repellent and toxicant against ticks. Entomologia Experimentalis et Applicata, Oxford, v. 53, n. 2, p. 111-116, 1989.

CRUZ, E. M.; COSTA JUNIOR, L. M.; PINTO, J. A.; SANTOS, D. A.; ARAUJO, S. A. de; ARRIGONIBLANK, M. D. E. F.; BACCI, L.; ALVES, P. B.; CAVALCANTI, S. C.; BLANK, A. F. Acaricidal activity of Lippia gracilis essential oil and its major constituents on the tick Rhipicephalus (Boophilus) microplus. Veterinary Parasitology, Amsterdam, v. 195, n. 1-2, p. 198-202, 2013.

DRUMMOND, R. O.; ERNEST, S. E.; TREVINO, J. L.; GLADNEY, W. J.; GRAHAM, O. H. Boophilus annulatus and B. microplus: laboratory tests of insecticides. Journal of Economic Entomology, Oxford, v. 66, n. 1, p. 130-133, 1973.

ENGSTRÖM, M. T.; KARONEN, M.; AHERN, J. R.; BAERT, N.; PAYRÉ, B.; HOSTE, H.; SALMINEN, J. P. Chemical structures of plant hydrolyzable tannins reveal their in vitro activity against egg hatching and motility of Haemonchus contortus nematodes. Journal of Agricultural and Food Chemistry, Washington, v. 64, n. 4, p. 840-851, 2016.

FERNÁNDEZ-SALAS, A.; ALONSO-DÍAZ, M. A.; ACOSTA-RODRÍGUEZ, R.; TORRES-ACOSTA, J. F.; SANDOVAL-CASTRO, C. A.; RODRÍGUEZ-VIVAS, R. I. In vitro acaricidal effect of tannin-rich plants against the cattle tick Rhipicephalus (Boophilus) microplus (Acari: Ixodidae). Veterinary Parasitology, Amsterdam, v. 175, n. 1-2, p. 113-118, 2011.

GIGLIOTI, R.; FORIM, M. R.; OLIVEIRA, H. N.; CHAGAS, A. C.; FERREZINI, J.; BRITO, L. G.; FALCOSKI, T. O.; ALBUQUERQUE, L. G.; OLIVEIRA, M. C. In vitro acaricidal activity of neem (Azadirachta indica) seed extracts with known azadirachtin concentrations against Rhipicephalus microplus. Veterinary Parasitology, Amsterdam, v. 181, n. 2-4, p. 309-315, 2011. 
GODARA, R.; KATOCH, M.; KATOCH, R.; YADAV, A.; PARVEEN, S.; VIJ, B.; KHAJURIA, V.; SINGH, G.; SINGH, N. K. In vitro acaricidal activity of Atropa belladonna and its components, scopolamine and atropine, against Rhipicephalus (Boophilus) microplus. The Scientific World Journal, New York, v. 2014, p. $713170,2014$.

GRISI, L.; LEITE, R. C.; MARTINS, J. R.; BARROS, A. T.; ANDREOTTI, R.; CANÇADO, P. H.; LEÓN, A. A.; PEREIRA, J. B.; VILLELA, H. S. Reassessment of the potential economic impact of cattle parasites in Brazil. Revista Brasileira de Parasitologia Veterinária, São Paulo, v. 23, n. 2, p. 150-156, 2014.

JONSSON, N. N. The productivity effects of cattle tick (Boophilus microplus) infestation on cattle, with particular reference to Bos indicus cattle and their crosses. Veterinary Parasitology, Amsterdam, v. 137, n. 1-2, p. 1-10, 2006.

LUCINI, L.; PELLIZZONI, M.; PELLEGRINO, R.; MOLINARI, G. P.; COLLA, G. Phytochemical constituents and in vitro radical scavenging activity of different Aloe species. Food Chemistry, London, v. 170, p. 501-507, 2015.

POLITI, F. A.; FIGUEIRA, G. M.; ARAÚJO, A. M.; SAMPIERI, B. R.; MATHIAS, M. I.; SZABÓ, M. P.; BECHARA, G. H.; SANTOS, L. C. dos; VILEGAS, W.; PIETRO, R. C. Acaricidal activity of ethanolic extract from aerial parts of Tagetes patula L. (Asteraceae) against larvae and engorged adult females of Rhipicephalus sanguineus (Latreille, 1806). Parasites \& Vectors, London, v. 5, p. 295, 2012.
RAHMANI, A. H.; ALDEBASI, Y. H.; SRIKAR, S.; KHAN, A. A.; ALY, S. M. Aloe vera: Potential candidate in health management via modulation of biological activities. Pharmacognosy Reviews, Mumbai, v. 9, n. 18, p. 120-126, 2015.

ROBBERTSE, L.; BARON, S.; VAN DER MERWE, N. A.; MADDER, M.; STOLTSZ, W. H.; MARITZOLIVIER, C. Genetic diversity, acaricide resistance status and evolutionary potential of a Rhipicephalus microplus population from a disease-controlled cattle farming area in South Africa. Ticks and Tick-Borne Diseases, Amsterdam, v. 2, n. 4, p. 595-603, 2016.

SIVIRA, A.; SANABRIA, M. E.; VALERA, N.; VÁSQUEZ, C. Toxicity of ethanolic extracts from Lippia origanoides and Gliricidia sepium to Tetranychus cinnabarinus (Boisduval) (Acari: Tetranychidae). Neotropical Entomology, Londrina, v. 40, n. 3, p. 375379, 2011.

STENDEL, W. The relevance of different test methods for the evaluation of tick controlling substances. The Journal of the South African Veterinary Association, Durbanville, v. 51, n. 3, p. 147-152, 1980.

WYK, R. D.; BARON, S.; MARITZ-OLIVIER, C. An integrative approach to understanding pyrethroid resistance in Rhipicephalus microplus and $R$. decoloratus ticks. Ticks and Tick-Borne Diseases, Amsterdam, v. 7, n. 4, p. 586-594, 2016. 
